Trakya Eğitim Dergisi

Cilt 9, Sayı 4

2019 Ek Sayı

Aralık 2019, 892-906

Geliş Tarihi: 08.03.2019

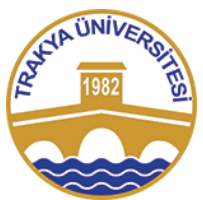

ISSN: 2630-6301
Trakya Journal of Education

Volume 9, Issue 4

2019 Additional Issue

December 2019, 892-906

Yayına Kabul Tarihi: 06.12.2019

DOI: $10.24315 /$ tred.537471

Araştırma Makalesi

\title{
Öğretmen Adaylarının Türk Eğitim Sistemine İlişkin Metaforik Algıları ${ }^{1}$
}

\section{Prospective Teachers' Metaphorical Perceptions Regarding Turkish Education System}

\author{
Halime ÖZTÜRK ÇALIKOĞLU², Mustafa Aydın BAŞAR ${ }^{3}$
}

\begin{abstract}
Öz: Bu çalışmanın amacı, öğretmen adaylarının Türk eğitim sistemine ilişkin algılarını metaforlar aracılığıyla ortaya koymaktır. Çalışma grubunu, Çanakkale Onsekiz Mart Üniversitesi, Eğitim Fakültesi’nde 2015-2016 eğitim-öğretim yılında son sınıfta okuyan dört farklı programdan toplamda 189 öğretmen adayı oluşturmaktadır. Katılımcılardan Türk Eğitim Sistemine ilişkin çizimler aracılığıyla görsel metaforlar üretmeleri ve ürettikleri bu metaforların nedenlerini açıklamaları istenmiştir. Toplanan veriler, içerik analizi yoluyla analiz edilmiştir. Bitki, hayvan, renk ve çizgilerle ifade edilen eğitim sistemi metaforları üç grup altında incelenmiştir: olumlu, olumsuz, olumluolumsuz. Çalışma sonuçları işlenen ve potansiyel işleyen girdi olarak öğretmen adaylarının daha çok olumsuz bir eğitim sistemi algılarının bulunduğunu göstermiştir. Öğretmen adayları eğitimi girdi olarak değerli ve kaçınılmaz bir yatırım olarak görürken, uygulamaya yönelik sorunların eğitimin hedeflerine ulaşmasına engel olduğunu düşünmektedir.
\end{abstract}

Anahtar sözcükler: Görsel metafor, Türk eğitim sistemi, öğretmen adayl

\begin{abstract}
This study explores the perceptions of prospective teachers related to education system of Turkey through metaphors. The study group consists of 189 prospective teachers attending four different programs at the Faculty of Education at Canakkale Onsekiz Mart University in the 2015-2016 academic year. The participants were asked to derive visual metaphors related to Turkish Education System via pictures, and to explain their reasons for their metaphors. Content analysis was applied to the collected data. Derived metaphors of plants, animals, colors and lines related to education system and organization were categorized into three groups: positive, negative and positive-negative. The results indicate that prospective teachers as processing and potential working input of the system have a more negative perception towards education system. In addition, the prospective teachers agree upon that education is a valuable investment; however, they think that the problems faced in practice hinder reaching the educational goals.
\end{abstract}

Keywords: Visual metaphor, Turkish education system, prospective teacher

\section{EXTENDED ABSTRACT}

\section{Introduction}

Schools are educational organizations which work based on the principles of system theory (Hoy and Miskel, 2010). Educational organizations as a social system have four components: goals, structure, process, and climate (Bursalığlu, 2015). Teachers as members of the educational organizations should be aware of and know well about the goals, structure and climate of schools and educational organizations. Thus, it is important that how organization members perceive these elements since teachers and prospective teachers are the individuals who would pursue the organizational goals.

Turkish education system has different problems as a result of innovative and social changes. Yet, it has a centralized structure which is associated as the source of several problems (Memduhoğlu, 2014). This makes schools influence decision-making process and governance of education. Thus, perceptions of school administrators and teachers regarding education system are important since it affects their works. As much as teachers do, prospective teachers should be able to be familiar and interpret the education system which would make contribution to development of education system. Prospective teachers represent both processed output and future working input of the system. In this context, this study explores the perceptions of prospective teachers related to education system of Turkey through visual metaphors and seeks to answer the following questions: system?

- What are the metaphors produced by the prospective teachers to describe Turkish education

\footnotetext{
${ }^{1} \mathrm{Bu}$ çalışma, '16th European Conference on Social and Behavioral Sciences' adlı 1-3 Şubat 2018 tarihlerinde Kuşadası'nda düzenlenen konferansta sözlü bildiri olarak sunulmuştur.

${ }^{2}$ Arş. Gör. Dr., Çanakkale Onsekiz Mart Üniversitesi, Eğitim Fakültesi, Eğitim Bilimleri Bölümü, Çanakkale, Türkiye, halimeozturk@comu.edu.tr, ORCID: https://orcid.org/0000-0003-0121-7124

${ }^{3}$ Dr. Öğr. Üyesi, Çanakkale Onsekiz Mart Üniversitesi, Eğitim Fakültesi, Eğitim Bilimleri Bölümü, Çanakkale, Türkiye, mbasar@comu.edu.tr ORCID: https://orcid.org/0000-0003-3678-4647
} 
- How do these metaphors reflect the problems of Turkish education system?

\section{Method}

The study group consists of 189 fourth grade prospective teachers attending four different teaching programs in the Faculty of Education at Canakkale Onsekiz Mart University in the 2015-2016 academic year. The participants were asked to derive visual metaphors related to Turkish Education System via pictures, and to explain their reasons for their metaphors. The prospective teachers were asked three questions to draw and explain their perceptions about Turkish education system:

1. If Turkish education system was a plant, what would it be? Please draw and explain your choice.

2. If Turkish educatin system was an animal, what would it be? Please draw and explain your choice.

3. As you consider the components (goals, structure, process, and climate) of Turkish education system, how would you draw using colors? Please draw and explain your choice.

Content analysis was applied to the collected data. The plants, animals, colors and lines were coded and categorized according to similar characteristics (Creswell, 2013).

\section{Results and Discussion}

Derived metaphors of plants, animals, colors and lines related to education system and organization were categorized into three groups: positive, negative and positive-negative. Of all three questions, the participant students produced more negatively metaphors. First, for plant metaphors, the prospective teachers expressed a wide variety of plants from flowers, tree, fruit-vegetable and grass groups. Cactus $(\mathrm{f}=32)$, tree $(\mathrm{f}=32)$, and daisy (13) were the most frequently drawn plant metaphors of the study. Second, for animal metaphors, the mostly frequently produced metaphors in positive category were cow $(\mathrm{f}=7)$ and bird $(f=5)$, in negative groups they were turtle $(f=19)$ and chameleon $(f=15)$, and it was fish $(f=4)$ in the positive-negative category. Third, for color and line metaphors, the participants used several colors $(\mathrm{f}=28)$ in the positive category while they use black $(\mathrm{f}=13)$ or black and other colors $(\mathrm{f}=23)$ in the negative category.

The results indicate that prospective teachers as processing and potential working input of the system have a more negative perception towards education system. There is educational research in which the metaphors used for education system are associated negatively compared to the ones used for school and education (Örücü, 2014). In this study, the prospective teachers agree upon that education is a valuable investment; however, they consider that the problems faced in practice hinder reaching the educational goals. In addition, the participants pointed out the frequently changes in education system and inconsistent education policies by using grass, daisy, butterfly, and chameleon. In the literature, similar results evidence that prospective teachers prioritized structural/managerial problems and changing/chaotic structure of education system among the other issues (Gözler, 2017; Kasapoğlu, 2016; Yaşar \& Sözbilir, 2017).

The study results suggest that prospective teachers could interpret the education system as an open system, and they produced more metaphors in the context of goals and process components. For instance, the participants criticized the education system considering its unsatisfactory development towards innovative and technological changes in the world, and competitive educational and learning process with several metaphors such as turtle and horse. Standardized testing and student assessment have also been stated in the other studies (Örücü, 2014; Yaşar \& Sözbilir, 2017).

Although the results are limited to the prospective teachers in this study, it would be better to reconsider the perceptions of future teachers about Turkish education system. Further, different studies may be designed with several data sources and data collection tools, which might inform policy makers and decision makers concerning the problems of education system.

\section{GíRiş}

Sosyal bir sistem olarak ele alınan eğitim örgütleri, çevresiyle sürekli alış-veriş içerisinde olan açık bir sistem özelliği göstermektedir. Eğitim örgütleri olarak okullar ise çevreden aldıkları girdileri, işleme süreci ile öğrenme, davranış değişikliği, yetenek ve beceri kazanımlarıyla çıktılara dönüştürür (Hanson 1996'dan aktaran İpek, 2014). Yeni yönetim yaklaşımlarıyla birlikte, eğitim örgütlerinin çevresel ve geleceğe yönelik değişiklikleri ve yenilikleri yönetebilmeleri daha da önem kazanır hale gelmiştir.

Sistem yaklaşımına dayalı olarak ele alınacak bir eğitim örgütü amaç, yapı, süreç ve hava olmak üzere dört boyutta ele alınabilir (Bursalığlu, 2015). Bunlardan amaç boyutu, örgüt etkinliklerinin ve eylemlerinin dayanağını oluşturur. Örgütlerin tümü belli amaçlara göre kurulur. Örgütün varoluş nedeni 
olan amaçlar, yöneticinin örgütteki madde ve insan kaynaklarını kullanma yönünü belirler. Öğretmenler, bu amaçları gerçekleştirecek en önemli unsurlardır. Eğer amaçlar iyi tanımlanamamışsa kaynakların hangi yönde ve nasıl kullanacağı belirlenemez (Koçel, 1983). Bu denli önemli olan amaçların, sistemin tüm çalışanları tarafından benimsenmeyişi sistemin önemli sorunlarındandır. Bu nedenle, her şeyden önce tüm öğretmenlerin daha öğrencilik yıllarından başlayarak amaçları benimsemeleri sağlanmalıdır. Aynı şekilde, öğretmen adaylarının yapı hakkındaki algılama ve değerlendirmeleri de önemlidir. Örgütsel amaçları gerçekleştirmek için biçimsel olarak onaylanmış ve süreklilik arz eden örgütsel düzenlemeler ve ilişkiler ağından oluşan (Aldemir ve Barbato, 1983) örgüt yapısı hakkında da sistemde görev alan ve alacak işgörenler bilinçlendirilmelidir.

Farklı ülkelerde, farklı örgütsel yapılar ve kültürler içinde yer alan insanların örgüt ve yönetimle ilgili bazı konularda çeşitli bakış açıları, değer yargıları, beklentiler, inançlar ve tutumlar içinde olabileceği ortadadır (Şişman, 1994). Örgütlerin bu kendine özgü yanları için kullanılan bir kavram da örgüt havasıdır. Örgüt amaç ve yapısına dayalı olarak işletilen bir örgütte, insan-insan ve insan-madde etkileşimine dayalı olarak bir hava, bir iklim oluşur. Eğitim örgütlerinin gelişmesi için olumlu bir hava-iklim yaratılmadıkça temel sistem olan okulun gelişmesi mümkün olamamaktadır. Örgütleri tanımanın yolu da, onların havasını ve iklimini tanımadan geçer.

Bir eğitim sistemi hangi biçimde yapılanırsa yapılansın, sistemi şekillendiren ve başarısını belirleyen, onun örgüt üyelerince nasıl algılandı̆̆ıdır. Bilincin önemli bir öğesi olan algılama, kişinin davranışını etkileyen, duyu organları ile beyin arasındaki örgütlü faaliyetleri içeren ve birçok özelliğe sahip bilişsel bir süreçtir. İnsanlar bu sayede sürekli çevresindekileri algılarlar ve algılamaya uygun davranışlarda bulunurlar, yorumlamalar yaparlar, kararlar verirler ve önlemler alırlar (Güney, 2000). Algılama, bir farkına varma, farkına varılma, bilgi setimiz içinde bir yer bularak yakıştırma ve söz konusu olguyu nitel ve nicel olarak yargilama süreci olarak da değerlendirilmektedir (Kaynak, 1990).

Gelecekte okul temel sistemini işletip etkili kılma görevini üstlenecek öğretmen adaylarının da sistemi nasıl algıladıkları, Türk eğitim sistemini onların nasıl yargılayıp değerlendiğini gösterir. Özellikle, sosyal sistemlerin algılanması, sistemin başarısının bireylerce rasyonel ve zihinsel olarak nasıl görüldüğüne bağlı olduğu kadar, duygusal olarak nasıl görüldüğüne de bağlıdır. Eğitim sisteminin işleyen girdisi olmaya aday eğitim fakültesi öğrencilerinin, Türk Milli Eğitim Sistemine yönelik algıları ve değerlendirmeleri önemlidir. Öğretmen adaylarının eğitim sistemini algılama biçimleri, onların gelecekteki görevlerini başarıyla yerine getirmelerini etkileyecektir.

Türk eğitim sistemi, yönetim yapısı itibariyle merkeziyetçi bir yapıya sahiptir. Eğitim-öğretimin planlanması, uygulanması ve okulların yönetilmesi açısından bu durum kararların alınmasında ve okulların uygulamada söz sahibi olabilmesinde oldukça etkilidir. Diğer yandan, merkeziyetçi yapı, Türk eğitim sisteminde karşılaşılan birçok sorunla da ilişkilendirilmektedir (Memduhoğlu, 2014). Eğitim sisteminin aksayan yönlerini tespit etmek için çeşitli düzeylerde geniş katılımlı toplantılar düzenlenmekte ve fikir alışverişi sağlanmaktadır. Ayrıca, eğitim alanında yapılan çalışmalar ile sistemin işleyen girdisi ve işlenen çıktısı durumundaki bireylerden de sorunlara yönelik veri toplanmaktadır. Bununla birlikte, metaforlar (mecaz/benzetme) da örgütlerin yapı ve işleyiş süreçlerini anlamlandırmak için bu çalışmalarda yararlanılan veri toplama yöntemlerinden biridir. Eğitim alanında daha çok çeşitli temel kavramlara ilişkin zihinsel algıları ortaya çıkarmaya yönelik çalışmalar olduğu görülmektedir (Yalçın ve Erginer, 2012).

Metafor çalışmalarına kaynaklık eden Lakoff ve Johnson (1980), çalışmalarında farkında olmadığımız kavramsal sistemimizi oluşturan düşünce ve deneyimlerimizin metaforik olduğunu ortaya koymuşlardır. Dolayısıyla birkaç kelimelik ifadelerden oluşan metaforlar, insanların günlük yaşamlarında sahip oldukları düşünce yapılarını ortaya koymada önemli bir araçtır. Başka bir deyişle, metaforik ifadeler, insanların zihnindeki karmaşı duygu ve düşünceleri içeren kavram haritalarını ortaya koymada önemli bir araçtır (Yıldızlı, Acar-Erdol, Baştuğ, Bayram ve Bayram, 2018). Bunun yanı sıra, metafor aracılığıla bireyler kendilerini daha yaratıcı bir şekilde ortaya koyabilirler. Örneğin sözel metaforların yanı sıra görsel metaforu, yazarak ifade etme kısıtlılığını yaşayan bireylerin resimle ve çizimlerle düşüncelerini daha etkili bir şekilde ifade etmesine firsat vermektedir (Tidwell ve Manke, 2009). Resim metaforu kullanmanın her ne kadar daha küçük yaştaki çalışma grupları için avantajları ön planda olsa da, hem sözel hem resim yoluyla anlatım yapılması katılımcıların ifadelerini zenginleştirmektedir.

Metaforlar soyut ve karmaşık kavramların somutlaştırılmasında aracı olmaktadır. Eğitim örgütleri özellikle sistem anlayışı ile birlikte yaşayan organizmalar olarak tanımlanmış ve incelenmiştir (Hoy ve Miskel, 2010). Morgan (1986) metaforun güçlü yanlarını vurgulayarak örgütsel yaşamın karmaşık ve paradoksal yapısını anlamak için makine, organizma, beyin, kültür, politik sistemler, ruhsal hastalıklar hapishanesi, akış ve dönüşüm ve baskı araçları gibi sekiz farklı örgütsel metafor ortaya koymuştur. Eğitim 
araştırmaları alanyazınında da, bu nedenlerle metafor sıklıkla tercih edilmektedir. Eğitim sisteminin önemli ögeleri olan öğretmen, öğrenme, öğrenci, eğitim programı, okul, yönetici, denetçi, sınıf yönetimi, okul yönetimi gibi birçok kavrama ilişkin öğretmen adayı, okul yöneticileri, öğretmenlerle yapılan birçok çalışma bulunmaktadır. Örneğin, öğretmen, öğrenci, okul, okul müdürü, okul yönetimi, müfettiş, eğitim programı gibi temel kavramları ele alan birçok çalışma yapılmıştır (Akan, Yalçın ve Yıldırım, 2014; Aykaç ve Çelik, 2014; Boyac1, 2009; Döş, 2010; Gültekin, 2013; Günbayı, 2011; Kadı ve Beytekin, 2017; Memduhoğlu ve Mazlum, 2014; Saban, 2009; Saban, Koçbeker ve Saban, 2006; Şahin ve Sabanc1, 2018a, 2018b; Sengul-Bircan, 2018; Yalçın ve Erginer, 2012; Yapıcı ve Yapıc1, 2013; Yildiz ve Gizir, 2018; Yıldırım, Ünal ve Çelik, 2011). Tüm bu kavramları içeren eğitim sistemini bütüncül olarak ele alan çalışmalar da alınyazında yer almaktadır (Erginer, 2011; Gözler, 2017; Kasapoğlu, 2016; Keser-Özmantar ve Yalçın-Arslan, 2019; Örücü, 2014; Yaşar ve Sözbilir, 2017). Bu çalışmada öğretmen adaylarının Türk eğitim sistemine ilişkin algıları üzerinde durulmuştur.

Eğitim sistemini bütün olarak alan çalışmaların, sistemi kapsamlı olarak değerlendirme firsatı verdiği görülmektedir. Örneğin, eğitim sistemi ile ilgili yapılan metaforik çalışmalardan biri olarak, Örücü (2014) öğretmen adaylarının okula, okul yöneticisine ve Türk eğitim sistemine yönelik kullandıkları metaforları incelemiş ve okul dişında olumsuz metaforların yüzdesinin daha fazla olduğunu bulmuştur. Türk eğitim sistemine ilişkin üretilen metaforlar öğretmen adaylarının olumsuz bir algıya sahip olduğunu göstermiş ve üretilen metaforların kaos, bürokratik işleyiş, politik, rekabete dayalılık, hedefe ulaşmada yetersizlik, verimsizlik gibi özellikleri ön plana çıkartmıştır (Örücü, 2014). Öte yandan Keser-Özmantar ve YalçınArslan (2019) eğitim sisteminin girdi-süreç-çıktı boyutlarıyla ilgili 13 farklı kavramı ayrı ayrı metaforlar aracılığıyla inceleyerek pedagojik formasyon ve eğitim fakültesi öğrencilerinin algılarını ortaya çıkarmıştır. Erginer'in (2011) çalışmasında ise eğitim sistemi metaforik olarak derinlemesine incelenerek, sistemin dinamikleri olumlu ve olumsuz yönleriyle ele alınmıştır. Dolayısıyla, eğitimi sistem olarak ele alan çalışmalarda bütünü oluşturan parçaların sistem içerisindeki işleyişi ortaya konulmuştur.

Eğitim sisteminin, sistem boyutlarıyla, öğretmenler kadar öğretmen adaylarınca da tanınması ve değerlendirilmesi, bu değerlendirme sonuçlarının sistemi geliştirme amacıyla kullanılmasına katkıda bulunacaktır. Öğretmenliğe adım atmak üzere eğitim almış ve belirli bir akademik seviyeye ulaşmış öğrenciler sistemin çıktısı durumundadır. Aynı zamanda birer öğretmen adayı olarak yakın gelecekte sistemin işleyen girdisi haline gelecek, sistemin değişimine katkı sağlayacak kişilerdir. Dolayısıyla, sistemin hem çıktısı hem de potansiyel girdisi olarak bu katılımcıların görüşlerini ortaya koymak iki boyutlu bir yarar sağlayacaktır. Sistemin doğru tanımlanması ve eleştirilmesi yoluyla, katılımcıların sisteme ilişkin güçlü, zayıf yönleri ortaya koyarak daha doğru bir bakış açısı geliştirilmesine katkı sağlayacaktır. Bu amaçla, araştırma kapsamında şu sorulara yanıt aranmıştır:

1. Ö̈̆retmen adaylarının Türk Eğitim Sistemini tanımlarken kullandıkları metaforlar nelerdir?

2. Kullanılan metaforlar Türk Eğitim Sisteminin sorunlarını nasıl yansıtmaktadır?

\section{YÖNTEM}

Öğretmen adaylarının Türk Eğitim Sistemine ilişkin algılarını metaforlar aracılığıyla ortaya koymayı amaçlayan bu çalışma betimsel bir araştırmadır. Bu amaçla, insanların dünyalarını ve yaşadıklarını nasıl anlamlandırdıkları ve yorumladıklarıyla ilgilenen nitel araştırma yöntemlerinden yararlanılmıştır (Merriam, 2013). Metafor konusu olarak "Türk Eğitim Sistemi” belirlenmiştir. Çalışmaya katılan öğretmen adaylarının "Türk Eğitim Sistemi”ne ilişkin düşünce ve yorumlarını resimle ve sözlü olarak ifade etmeleri istenmiştir.

\section{Çalışma Grubu}

Araştırmanın çalışma grubunu, Çanakkale Onsekiz Mart Üniversitesi, Eğitim Fakültesinde 20152016 eğitim-öğretim yılında eğitim gören dört farklı öğretmenlik programından toplam 189 son sınıf öğrencisi

Tablo 1. Çalışma grubu

\begin{tabular}{lc}
\hline Öğretmenlik Programı & Katılımcı Sayısı \\
\hline Coğrafya Öğretmenliği & 29 \\
Tarih Öğretmenliği & 26 \\
Din Kültürü ve Ahlak Bilgisi Öğretmenliği & 59 \\
Okul Öncesi Öğretmenliği & 75 \\
& \\
\hline
\end{tabular}




\section{Veri Toplama}

Öğretmen adaylarının bitki, hayvan ve renk-çizgiler yoluyla Türk Eğitim Sistemine ilişkin zihinsel algıları belirlenmiştir. Öğretmen adaylarının resimden yararlanarak metaforik anlatımla Türk Eğitim Sistemini nasıl algıladıklarını daha güçlü şekilde ortaya koymaları sağlanmıştır. Katılımcılardan Türk Eğitim Sistemine ilişkin benzetmeler üretmeleri ve nedenlerini açıklamaları istenmiştir. Katılımcılara aşağıda verilen üç açık uçlu soru sorulmuştur ve cevaplarını resimlerle uygun gördükleri renkleri kullanarak anlatmaları istenmiştir.

1. Milli Eğitim Sistemi bir bitki olsaydı ne olurdu? Çizin ve bir cümleyle açıklayın.

2. Milli Eğitim Sistemi bir hayvan olsaydı ne olurdu? Çizin ve bir cümleyle açılayın.

3. Milli Eğitim Sisteminin amaç, yapı, süreç, hava (ilişkiler) boyutlarıyla düşündüğünüzde, renk ve ifadelerle nasıl çizerdiniz? Çizin ve bir cümleyle açıklayın.

\section{Veri Analizi}

Öğretmen adaylarının metafor sorularına ilişkin verdikleri metafor cevapları, açıklamaları ve çizdikleri resimler içerik analizi yöntemiyle analiz edilmiştir. İçerik analizinde temel olarak kod ve kategoriler oluşturma uygulanmıştır (Creswell, 2013). Türk Eğitim Sistemine ilişkin yapılan bitki, hayvan, örgütsel boyutları ile ilgili benzetmeleri birer kod olarak alınmış, benzer özelliktekiler gruplandırılmış ve temalar altında toplanmıştır. Ayrıca, katılımcıların yaptıkları metaforları neden seçtiklerine ilişkin açıklamaları incelenerek bulgular zenginleştirilmiş ve verilerin geçerliliği güçlendirilmiştir. Bazı metafor örnekleri resimleriyle Ek-1'de verilmiştir.

\section{BULGULAR}

Çalışmanın bulguları, araştırma sorularını temsil eden alt başlıklar halinde aşağıda sunulmuştur. Öncelikle katılımcıların Türk Eğitim Sistemini tanımlamak için kullandıkları metaforlar bitki, hayvan ve renk-çizgiler başlıkları altında verilmiştir. Daha sonra kullanılan metaforların, Türk Eğitim Sistemine ilişkin ne tür sorunları yansıttığı açıklanmıştır.

\section{Eğitim Sistemi Bir Bitki Olsaydı}

Çalışmaya katılan öğretmen adaylarının ‘Türk Eğitim Sistemi bir bitki olsaydı, ne olurdu?' sorusuna verdikleri cevaplara göre, toplamda 56 farklı metafor üretilmiştir. Öğretmen adaylarının ürettikleri bu bitki metaforları dört grup altında toplanmıştır: ağaç, çiçek, otlar ve meyve-sebze. Bu gruplar altında metaforlar ise üç tema altında değerlendirilmiştir: (1) olumlu, (2) olumsuz ve (3) hem olumsuz hem olumlu. Metaforların oluşturduğu gruplar olumlu, olumsuz veya olumsuzdan olumluya olmasına göre temaları temsilen aşağıda verilen şekilde sayısal doğru üzerindeki üç bölgede gösterilmiştir (Bkz. Şekil 1). Araştırmacılar sayısal doğrunun pozitif ve negatif yönlerini metaforların olumlu-olumsuz özelliklerini göstermek için kullanmışlardır. Olumlu teması pozitif bölgedeki birinci grup olarak (G1), Olumsuz teması negatif bölgedeki ikinci grup olarak (G2) ve hem olumsuz hem olumlu teması alttaki üçüncü bölge olarak (G3) gösterilmiştir. 


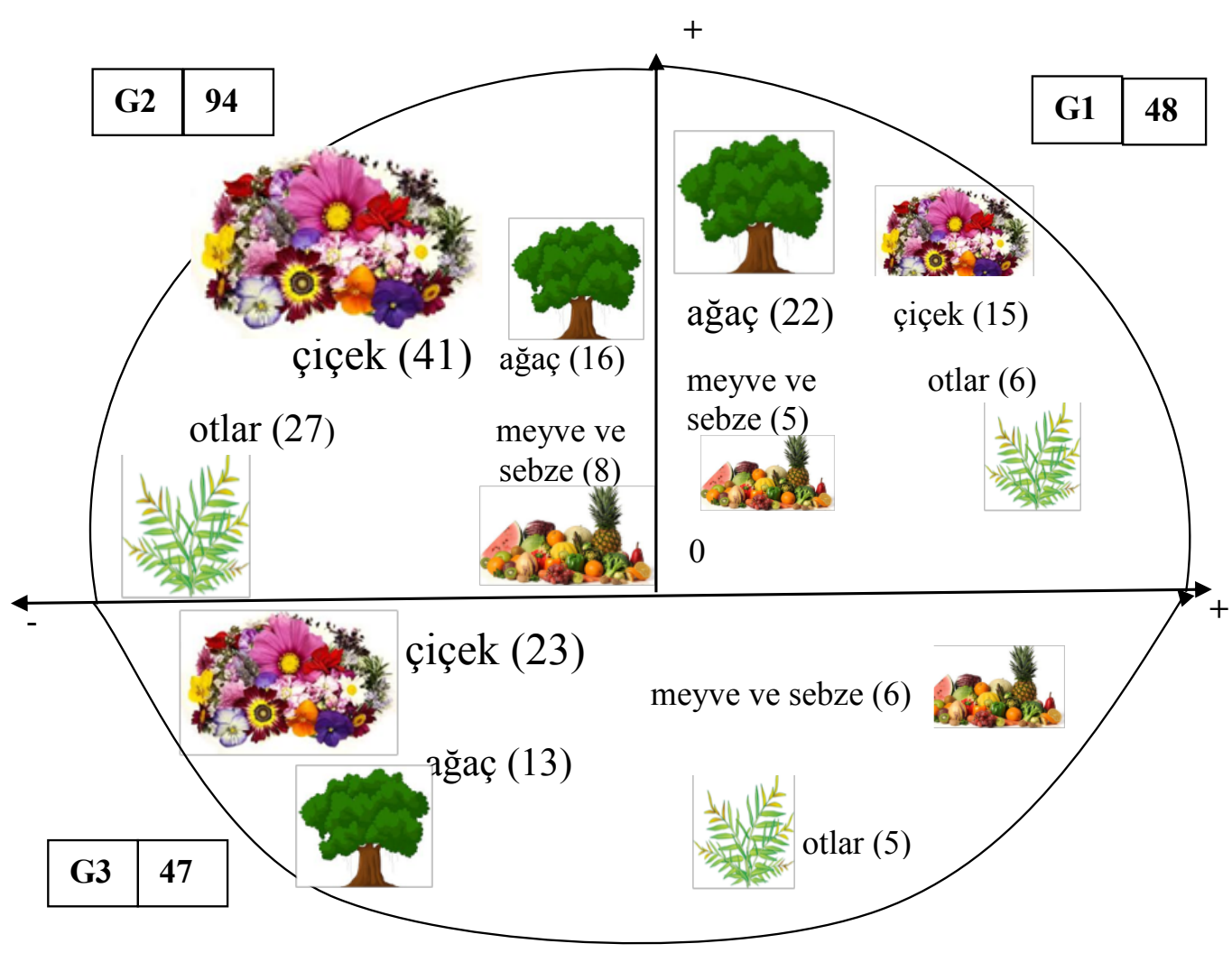

Şekil 1. Türk eğitim sistemine ilişkin öğretmen adaylarının ürettikleri bitki metaforları

Şekil 1'de görüldüğü üzere, çalışmaya katılan öğretmen adayları çoğunlukla olumsuz açıklamalar içeren metaforlar üretmişlerdir ( $\mathrm{G} 2 \mathrm{f}=94)$. Olumsuz temasında yer alan metaforların yarısına yakınını çiçek grubu oluşturmakta $(\mathrm{f}=41)$ ve bunu otlar grubu $(\mathrm{f}=27)$ ve daha sonra ağaç grubu $(\mathrm{f}=16)$ izlemektedir. Diğer yandan, olumlu teması altında 48 metafor yer almıştır (G1f=48) ve metaforların çoğu ağaç metaforlarından $(\mathrm{f}=22)$ ve daha sonra çiçek metaforlarından $(\mathrm{f}=15)$ oluşmaktadır. Üçüncü tema olan hem olumsuz hem olumlu altında ise 47 metafor bulunmaktadır ( $\mathrm{G} 3 \mathrm{f}=47$ ) ve çoğunluğunu çiçekler ( $\mathrm{f}=23$ ) ve ağaçlar ( $\mathrm{f}=13$ ) oluşturmaktadır. Ayrıca çalışmada en çok tekrar eden bitki metaforları şu şekildedir; kaktüs ( $\mathrm{f}=32)$ ve ağaç $(\mathrm{f}=32)$. Bunları takiben papatya $(\mathrm{f}=13)$, çiçek $(\mathrm{f}=9)$, gül $(\mathrm{f}=9)$, sarmaşık $(\mathrm{f}=8)$, ot $(\mathrm{f}=8)$ ve çam ağacı $(\mathrm{f}=8)$ en çok tekrar eden bitki metaforları arasında yer almıştır.

Öğretmen adaylarının ürettikleri metaforlara ilişkin yaptıkları açıklamalardan olumlu tema altında Türk eğitim sisteminin güçlü ve çok yönlü özelliklerinin ortaya çıkarıldığı görülmüştür. Örneğin, katılımcılar ağaç metaforunu derin kökleri, meyve vermesi ve yeşil olması gibi özelliklerinden dolayı seçtiklerini belirtmişlerdir. Katılımcılardan biri (K86) bu durumu şöyle açıklamıştır: "Türk Ĕgitim Sistemi bir ăgaç olurdu çünkü meyve verir ve yeşil dallarıyla sürekli yukarı doğru büyür.". Başka bir katılımc1 ise şöyle ifade etmiştir (K100): "Birçok alanda etkileri olan sisteme benzeyen köklü bir ă̆aç olurdu.". Olumlu metaforlar üreten diğer bazı katılımcıların yaptıkları açıklamalar şu şekildedir:

"Topră̆a ekilen buğday soğuk, sıcak, yağmur, kar gibi zorluklar arasında bir ekilen buğday başağında onlarca olarak oluşur, yani ĕ̆itimdeki öğrenci zamanla da başka öğrencilere öğretici olarak tekten çokluğa geçerler." (buğday, K138)

"Türk Milli Eğitim sistemi sağlam kökleri olan bir çınar ağacıdır. Kapsamlıdır, her dalında yeni bir filiz vardır. Ve sağlam kökleri de geçmişe dayanır." (çınar ağacı, K44)

Diğer taraftan bazı metaforları bazı katılımcılar olumlu anlamda kullanırken, bazı katılımcılar ise olumsuz anlamda kullanmıştır. Örneğin papatya metaforu hem olumlu hem de olumsuz teması altında yer almıştır. Olumlu tema altında papatya metaforunu kullanan katılımcılardan biri, "Papatyanın dalları gibi birbirine sımsıkı bağll ve ayrı yönlere bakabilen yapraklardan oluşmall." (K28) şeklinde ifade ederken; bir başka katılımcı da "Milli Ĕgitim sistemi kendini yenileyen, üretici olan ve aydınlı̆̆a dönük olmalıdır." (K79) 
veya "Her kişi özeldir. Nerede olursa olsun onlarca eğitim verilmesi gerekir. Papatya gibi eğitim her yerde olmalıdır.” (K159) şeklinde papatya metaforunu neden seçtiklerini açıklamıştır. Diğer yandan olumsuz tema altında papatya metaforunu kullanan bir katılımcı ise şöyle açıklama yapmıştır (K4): "Her sene papatya falına benzerlikte yapılan değişiklikler..." (papatya). Olumsuz teması altında metaforlar üreten katılımcıların yaptıkları bazı diğer açıklamalar şu şekildedir:

“Ne kadar sevsek de gidip sarılamıyoruz." (kaktüs, K129)

"Yanlış yönlendirilen veya potansiyelleri ögütülen bireyleri ifade ediyor." (etçil bitki, K19).

"Büyümek istedikçe birbirine dolanan ..." (sarmaşık, K60)

"Nilüfer köksüzdür. Durgun sularda olur. En ufak dalgada yok olur." (nilüfer, K21)

"Yosun olurdu yosun mide bulandırıcıdır. Ayağa takllır." (yosun, K96).

Ot metaforunu olumsuz tema altında kullanan katılımcılardan biri (K3) şöyle açıklamıştır: "Ot bitkisi her mevsim yeşerir, kisa bir süre sonra kurur ve ölür. Eğitim sistemimizde her yll sürekli değişiklikler olmaktadır. Köklü bir sistem değildirler. Her gelen Milli Eğitim Bakanı bir önceki sistemi baştan yeniliyor.". Bir diğer katılımc1 ise (K114) şöyle belirtmiştir: "Ot olurdu. Çünkü insanlar aynı biçimde, kendi isteklerine göre, kendi yeteneklerine göre değil nerde menfaat varsa orda ot gibi biten insanlar yetiştiriyor. Ot gibi yavan bir sistem."

İlginç gelen bazı bitkiler de katılımcılar tarafindan dile getirilmiştir. Örneğin; bir okul öncesi öğretmen adayı (K126) eğitim sistemini gilaburu bitkisine benzeterek şu açıklamayı yapmıştır: “... şekersiz tadı kötü ve her şeye faydalı. Şifalı bir bitki.". Diğer taraftan, sınav sistemini eleştiren bir öğretmen adayı eğitim sistemini acı bibere benzeterek (K55) şöyle demiştir: "Sistem içerisinde sürekli öğrencinin yıllarını çalan bir sinav sistemi var. Bu kişiye psikolojik bir acı veriyor."

Hem olumsuz hem olumlu teması altında belirtilen metaforlar çoğunlukla eğitimin sonunda elde edilecek yararları vurgulanarak gösterilmesi gereken bir çaba olduğuna vurgu yapmaktadır. Örneğin, bir öğretmen adayı eğitim sistemini zeytin ağacına benzeterek şöyle açıklamıştır (K57): "E ğer bakımı, suyu, budamaları zamanında ve güzel bir şekilde yapılırsa çok verimli bir zeytin ăgacı meyvesinden de her türlü yararlanılabilir. Gerek sofrada kahvaltılık, gerek yăg olarak kullanılmasıyla tıpkı nitelikli bir eğitim almış ögrenci gibi çok faydalıdır.”. Ayrıca eğitim sisteminin hem olumlu hem olumsuz yanlarını belirterek üretilen metaforlar da hem olumsuz hem olumlu teması altında değerlendirmiştir. Örneğin, bir katılımc1 eğitim sistemini baobab ăgacına benzeterek şöyle açıklama yapmıştır (K184): “Aynı bu bitki gibi çok büyük görünen bir sistem çok şey vaad ediyor. Ama bu bitki gibi kapalı tohumlarl var. Bu bitkiden gövdesinden ateş düşürücü falan yapılıyor, çok yararlı ama tohumlar kapalı sistem aynen [eğitim sistemi gibi.]”.

Kaktüs bitkisi genel olarak olumsuz olarak ifade edilse de bazı katılımcılar hem olumsuz hem olumlu grubu içerisinde ifade etmişlerdir. Örneğin, bir okul öncesi öğretmen adayı şöyle belirtmiştir (K53): "Milli Ĕgitim sistemi bence bir kaktüs olurdu. O iklim şartlarında içindeki suya ulaşmak için elinize batan dikenlere katlanmak zorundasınız. Çocuklar da böyledir. Onların geçmişten getirdiği birikimi değerlendirmek, iyi bir birey yetiştirmek için zorluklara katlanmak gerek.”. Başka bazı öğretmen adayları ise bu tema altındaki metafor seçme nedenlerini şöyle açıklamıştır:

"Eğer iyi bir şekilde yetiştirilirse kaktüsün güzel açan çiçekleri gibi bizlerden de güzel bir gelecek sunabilecek nesiller yetişebilir." (kaktüs, K156)

"Sistem karlar içinde, zorluklar içinde büyümeye çalışan bir kardelendir." (kardelen, K91)

"Dikenli bir gül gibi zahmetli bir yol, kimisi açıyor kimisi açmadan soluyor." (gül, K144)

"Gülün dikenleri gibi olur, insanlara batar ama sistem gerektiği gibi olursa dikenlerinden önce gülün güzelliği algilanır.” (gül, K93)

\section{Eğitim Sistemi Bir Hayvan Olsaydı}

Türk Eğitim sisteminin öğretmen adayları tarafından nasıl algılandığının hayvan metaforları aracılığıyla belirlenmesine ilişkin elde edilen bulgular Şekil 2'de özetlenmiştir. Öğretmen adayları Türk Eğitim Sistemini tanımlamak için toplamda 61 farklı hayvan metaforu üretmişlerdir. Şekil 2'de görüldüğü üzere, öğretmen adaylarının kullandıkları hayvan metaforları olumlu (G1), olumsuz (G2) ve hem olumsuz hem olumlu (G3) olmak üzere üç tema altında toplanmıştır. Temalar altında kullanılan metaforlara 
bakıldığında, öğretmen adaylarının çoğunlukla negatif anlamlar yükledikleri hayvan metaforlarını tercih etmişlerdir ( $\mathrm{G} 2 \mathrm{f}=126)$. Bunu takiben olumlu metaforlar $(\mathrm{G} 1 \mathrm{f}=49)$ ve daha sonra hem olumsuz hem olumlu anlamdaki metaforlar $(\mathrm{G} 3 \mathrm{f}=14)$ gelmektedir.

Temalar altında kullanılan hayvan metaforları incelendiğinde, olumlu gruptaki en fazla kullanılan hayvan metaforu inek $(\mathrm{f}=7)$ olup bunu kuş $(\mathrm{f}=5)$, tırtıl $(\mathrm{f}=4)$ ve aslan $(\mathrm{f}=4)$ izlemektedir. Olumsuz grup altında en fazla belirtilen hayvan metaforu ise kaplumbağa ( $\mathrm{f}=19)$ olmuş, bunu bukalemun $(\mathrm{f}=15)$, at $(\mathrm{f}=5)$, kedi $(\mathrm{f}=5)$, kelebek $(\mathrm{f}=5)$ ve ahtapot $(\mathrm{f}=4)$ izlemiştir. Hem olumsuz hem olumlu grubunda ise öne çıkan hayvan metaforu balık $(\mathrm{f}=4)$ olmuştur. Her grupta öne çıkan hayvan gruplarının farklı hayvanlar olduğu görülmektedir. Her bir gruptaki hayvan metaforlarının seçilme nedenlerine ilişkin açıklamalar aşağıda verilmiştir.

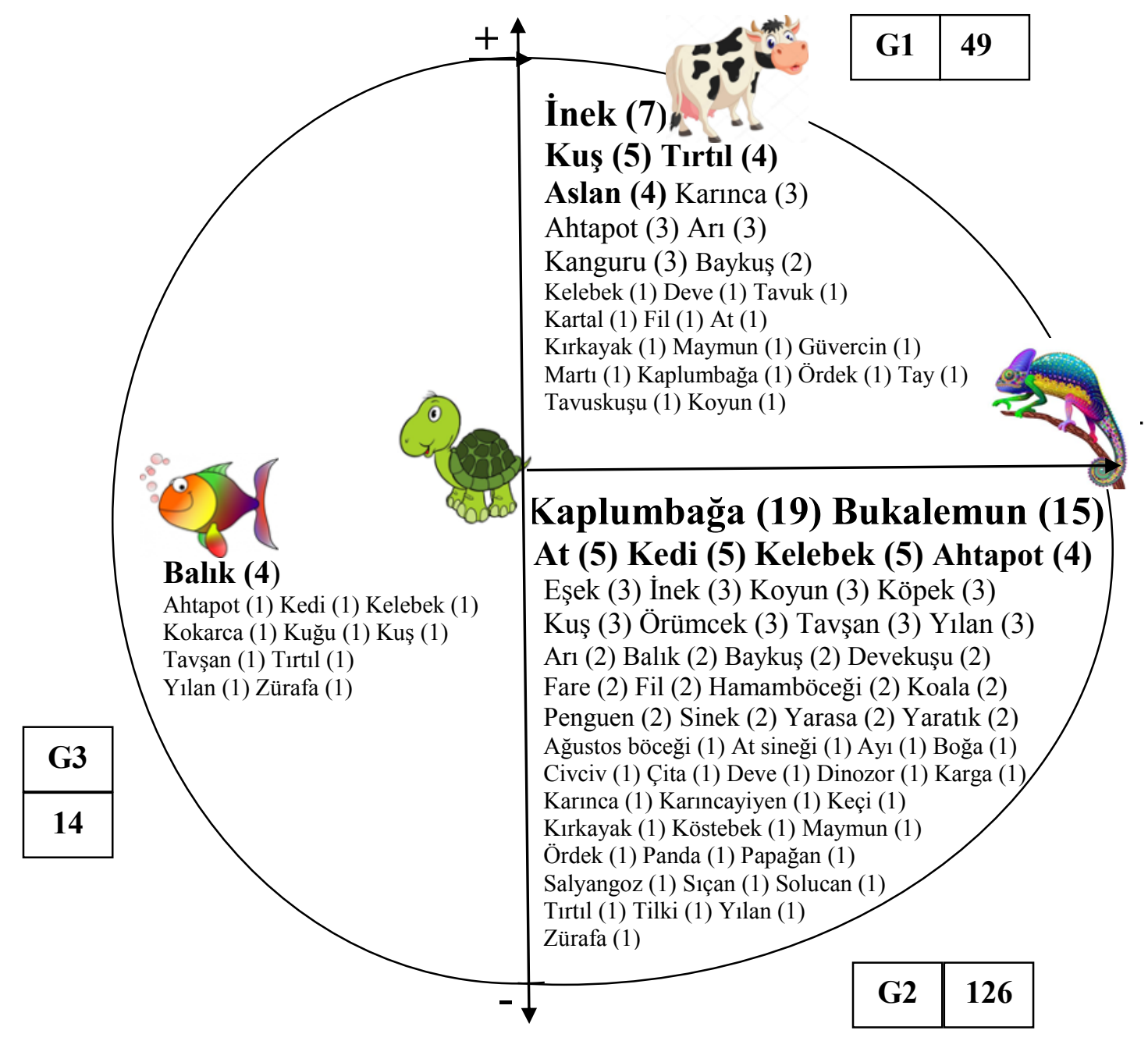

Şekil 2. Türk eğitim sistemiyle ilgili hayvan metaforları

Olumlu grup içinde en fazla yer alan hayvan metaforlarına bakıldığında, katılımcılar Milli Eğitim sistemi aracılığıyla eğitimin bireyler ve toplum için faydaları olduğunun ön plana çıkarıldığı görülmektedir. Katılımcılar, çocukların eğitim sayesinde iyi yetişerek ülkenin gelişmesi ve kalkınması için topluma faydalı bireyler haline geleceklerini belirtmişlerdir. Aşağıda bu açıklamaları vurgulayan alıntılar verilmiştir:

"Milli Eğitim Sistemi bir hayvan olsaydı ot yiyerek süt veren farklı sonuçlar elde edilen her kısımı faydall olan bir inek olurdu." (inek, K119)

"Eğitim Sistemi bir kuş gibidir, sizi farklı diyarlara götürür." (kuş, K109) 
"Tırtıl olurdu. Okul öncesinden başlayarak insanları büyütüp, eğitip kelebeğe dönüşürmeye yardım eder." (tırt1l, K122)

"Aslan hayvanların kralıdır. O yüzden herşey ona göre düzenlenir. Milli Eğitim Sistemi de her şeyin başıdır. Ona göre eğitim düzenlenir.” (aslan, K49)

"Milli Eğitim Sistemi bir hayvan olsaydl ahtapot olurdu. Çok kollu ve ulaşllmak istenen hedeflere bütün kolların kenetlenmesiyle ulaşır." (ahtapot, K88)

"Arı nasıl bütün çiçekleri dolaşarak tozlaşmayı, üremeyi sağlayıp, neslimizin devamı için önemliyse Türk eğitim sistemi de bizim ĕgitim-öğretim için de öyledir." (arı, K47)

"Ülkenin gelişmesi için hiçbir elemanın, öğesinin boş durmaması gereken, sistemdeki en ufak bir çabanın meyvelerini ileride misliyle alabileceğimiz bir sistemdir." (karınca, K57)

Olumsuz grup en çok metaforun üretildiği tema olarak yer almıştır. Katılımcılar eğitim sisteminin aksayan yönlerini, eksikliklerini ve bunların bireyler üzerindeki etkilerini metaforlar aracılı̆̆ıyla ifade etmişlerdir. Örneğin, en çok kullanılan metafor olan kaplumbağa eğitimi sisteminin yavaş işlemesi ve ihtiyaçları karşılamada geride kalmasına vurgulamada kullanılmıştır. Bir katılımcı bunu "kaplumbağa gibi bir eğitim sistemi var. Çok geriden takip ediyor ve çok yavaş ilerliyor. (K62)" diyerek ifade ederken bir başka katılımcı da "hevesleri, hedefleri ve idealleri kısıtlı çerçevede ancak kabuğunun içinde ters dönmüş bir nesil yetişir. (K140)" şeklinde belirtmiştir.

Kaplumbağa metaforundan sonra en çok tekrar eden hayvan metaforu bukalemun olmuştur. Katılımcılar eğitim sisteminde yaşanan politika değişikliklerine ve sıklıkla gerçekleşen politika reformlarına dikkat çekmek için bukalemunun ortamına göre renk değiştirme özelliğine ithafen bu metaforu kullanmışlardır. Bir öğretmen adayı bu durumu şöyle açılamıştır (K9): "Her şeyden etkilenir. Siyasetten, ekonomiden, insanların keyfi isteklerinden etkilenir ve ögrencileri yem haline dönüşürür. Sömürülecek bir yem.". Başka bir katılımc1 ise (K17) "Hükümetler săg olsun. bir renk tutturamadık." şeklinde ifade etmiştir.

Bazı katılımcılar eğitim sisteminin bireyleri sınav odaklı yetiştirmesini eleştirerek benzetmelerde bulunmuştur. Örneğin, bir öğretmen adayı eğitim sistemini yarış atına benzeterek (K54) şöyle belirtmiştir: "Milli Ĕgitim sistemi yarış içinde olan öğrenci profili çizer, ögrencilerin yaşamı at yarışından farksızdır. Herkes çocuğunun en iyisi olsun, çocuğu birinci olsun ister. Bu durum eğitim sistemimizin sonucudur.". Başka bir katılımcı (K27) ise rekabete dayalı sistemi at metaforuyla şöyle ifade etmiştir: "Koş koş koş, nereye belli değil.". Diğer taraftan, bir öğretmen adayı hem kaplumbağa hem de at metaforlarını kullanarak eğitim sistemine yönelik algısını şöyle belirtmiştir (K3): "Yarış atı gibi görünse de, aslında kaplumbağaya benziyor. Ĕ̌itim sistemimiz sürekli yarıştıran ancak öğrencilere baktığımızda pek yol alamayan. Örneğin; senelerdir ingilizce dersi görüyorum. Yüksek puanla geçiyoruz ama konuşamıyoruz.".

Türk Eğitim Sistemini ahtapota benzeten bir katılımcı (K10) bireylerin eğitim sistemi içindeki çaresizliğini işaret ederek şöyle açıklamada bulunmuştur: "Istediği gibi sarıyor, istediği gibi bizi slkıyor. Biz eline düşmüss, kurtulamıyoruz, sadece elinde kıvranıyoruz.". Diğer yandan, eğitim sisteminin çıktılarına ilişkin eleştirileri ele alan bazı metaforlar ile aşağıdaki gibi açıklanmıştır:

"Fare olurdu. Çünkü bizi deney faresi gibi deniyorlar. Sonuçlarına biz katlanıyoruz. Kayıp bir nesil yetişiyor." (fare, K114)

"Yeni mezun olmuş, genç ögretmenler çalışma hayatlarına atıldıklarında olayın hiç de hayal ettikleri gibi olmadı̆̆ını fark ederler, eğitim sistemi bu coşkulu genç kanı sivrisinek gibi emer, sıradanlaştırır." (sinek, K43)

Üçüncü tema olarak yer alan hem olumsuz hem olumlu anlam içeren metaforlar sınırlı sayıda yer almıştır (Bknz. Şekil 2). En fazla tekrar eden balık metaforunu bir katılımcı şu şekilde açıklamıştır (K37): "Milli Ë̆itim sistemi somut bir şekilde görülmez, ona her yerde rastlamayız. Balık gibidir, ona ulaşabilmek için su altına inmemiz gerekir.”. Bu gruptaki metaforlara birkaç örnek aşağıda verilmiştir:

"Bir hayvan olsaydı kuş olurdu. Çünkü bazı noktalarda bize çok yakın olurken bazı noktalarda elimizle tutamayacağımız kadar uzaktır." (kuş, K123)

"Eğitim sistemi bir zürafaya benzemeli beslenmek için dallarda ki yapraklara ve gölde ki suya ulaşabilmeli. Tüm zorluklara rağmen tüm çocuklara ulaşabilmeli.” (zürafa, K53). 


\section{Renk ve Çizgilerle Türk Eğitim Sistemi}

Türk Eğitim Sistemine ilişkin öğretmen adaylarını algılarını belirlemek üzere kullanılan üçüncü soru "Türk Eğitim Sistemini bir bütün olarak düşündügünüzde (amaç, yapl, süreç, hava boyutlarl) renk ve çizgilerle nasıl ifade edersiniz?” ile öğretmen adaylarının eğitim sistemini örgütsel boyutlarıyla bütüncül bir şekilde değerlendirmeleri istenmiştir. Öğretmen adaylarının kullandıkları renk ve çizgiler dikkate alınarak yaptıkları açıklamalar analiz edilerek eğitim sisteminin örgütsel boyutlarına yönelik düşünceleri renk ve boyutlar üzerinden bulgular halinde aşağıda sunulmuştur.

Öncelikle katılımcıların 116'sı için renk kullanımı ve 26 tanesi için çizgilerin tespiti yapılabilmiştir. Kullanılan bu renkler ve çizgiler ve de açıklamalar da göz önünde bulundurularak üç grup altında analiz edilmiştir: (1) olumlu, (2) olumsuz ve (3) hem olumlu hem olumsuz. Aşağıdaki şekilde renk ve çizgi tespiti yapılan tüm katılımcıların kullandıkları renklerin ve çizgilerin gruplara göre dağılımı verilmiştir. Şekil 3'te görüldüğü üzere değerlendirmeye alınan katılımcıların \%44'ü renk ve çizgileri olumsuz anlamlarda kullanmıştır. Olumlu grupta yer alanların oranı $\% 36$, hem olumlu hem olumsuz anlamda kullanılanların oranı ise \%20'dir.

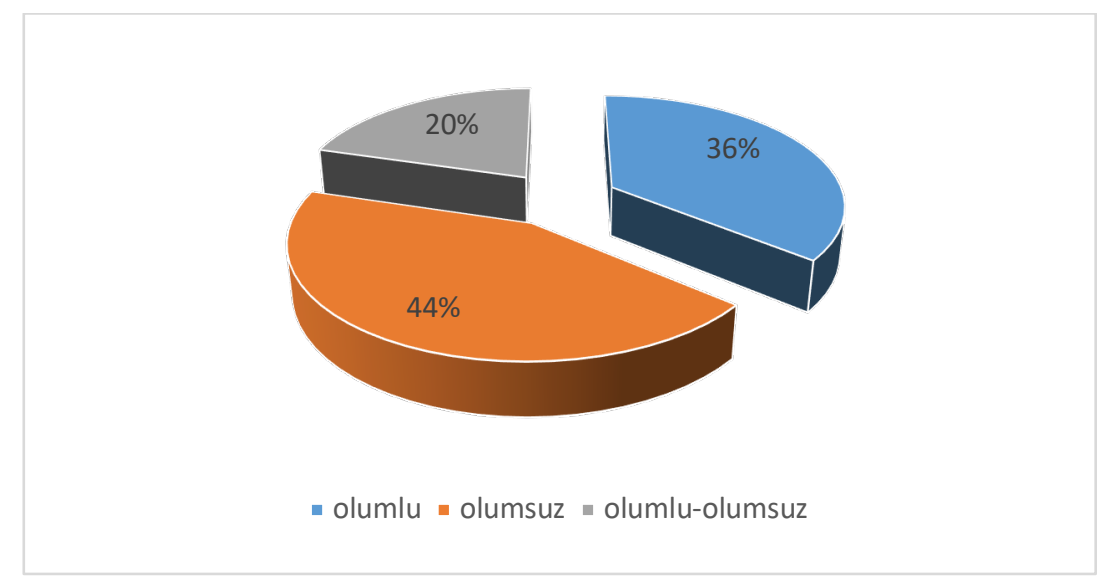

Şekil 3. Eğitim sistemine ilişkin kullanılan renk ve çizgilerin temalara göre dă̆ğımı

Olumsuz grupta sadece siyah veya siyahın diğer renklerle kullanımı veya renkli başlayıp siyahla biten olumsuz nedenleri içeren ifadeler yer almıştır. Sarı dışında koyu ve soğuk renkler kullanılmıştır. Olumsuz tema altında öğretmen adaylarının en fazla siyahla beraber birkaç renk birlikte $(\mathrm{f}=23)$ veya siyah (f=13) kullandıkları görülmektedir. Örneğin tünel metaforunu çizen bir öğretmen adayı siyah renk kullanarak açıklamasını şöyle yapmıştır (K50): "Sistemden çıktı̆̆ımızda sonumuzun nereye varacağını bilemeden ilerliyoruz.". Eğitim sistemi sürecini eleştiren bazı katılımcılar sisteme girmeden önce bireyleri mavi, rengarenk gibi renklerle ifade ederken, eğitim sisteminden çıkışta ise bireyleri siyah renkle ifade etmişlerdir. Örneğin, bir öğretmen aday1, siyah ve mavi renklerini kullanarak nedenini şöyle belirtmiştir (K17): "Yolun başında hepimiz maviydik.". Buna ek olarak, bir öğretmen adayı siyahla beraber farklı renklerle çizdiği eğrilerle bir karmaşıklık çizerek bunu "Devamlılı̆̆ın olmadı̆̆ yerde düzen, düzensizliktir." (K142) şeklinde açıklarken, bir başka öğretmen adayı ise rengarenk başlayan siyah renkle biten bir gökkuşağı çizerek "Eğitememek bizim işimiz." (K4) diyerek açıklamıştır.

Olumlu grupta kullanılan renkler en fazla üçten çok renk birlikte kullanılan veya rengarenk ifadeleriyle açıklanmış olumlu nedenleri olan ifadelerdir. Bunun dışında yeşil, beyaz, kırmızı, mavi, turuncu, kahverengi ve sarı diğer kullanılan renklerdir. Olumlu renkler içinde öğretmen adayları, en fazla birkaç rengin birlikte kullanıldığı veya rengarenk $(\mathrm{f}=28)$ vurgulamasının yapıldığı görülmüştür. Bunları takiben yeşil $(\mathrm{f}=6)$, ve beyaz $(\mathrm{f}=4)$ renkleri en fazla tercih edilmiştir. Rengarenk veya farklı renkleri kullandıkları çizimler yapan katılımcılar, eğitim sisteminin farklı boyutlardan oluştuğunu ve bir bütün olarak çalıştığına vurgu yapmışlardır. Ayrıca eksik kısımların sistemi nasıl etkilediğini ifade ederek bütün olarak çalışmasının önemini belirtmişlerdir. Örneğin, katılımcılardan biri, rengarenk bir yay metaforunu kullanarak çizimini gerçekleştirmiş ve şu açıklamayı yapmıştır (K45): "Milli Eğitim sisteminin amaçları, yapı ve süreç, hava boyutlarını düşündü̈̆̈̈mde aklıma rengarenk bir yay geldi. Çünkü düşündügümüz boyutlar birbiriyle ilişkili ve birbirini tamamlayıcı niteliktedir. Yayın bir yeri koptuğunda aralarında kopukluk olur.". Bir başka öğretmen adayı ise tekerlek çizerek farklı renkler kullanmış ve şöyle açıklama 
yapmıştır (K47): "Teker teker bakıldı̆̆ında hepsinin farklı görevleri varken, merkez de hepsi birbiriyle bütünleşmiştir. Temel de aynı şey için çalışırlar. Bir bütünken hareket edebilmek için.".

Olumlu-olumsuz grupta ise yine siyahın diğer renklerle kullanımı veya rengarenk olup açıklamasında eğitim sisteminin hem olumlu hem olumsuz yanlarını vurgulayan ifadeler bulunmaktadır. Hem olumlu hem olumsuz grup altında yer alan katılımcılar genel olarak siyahla birlikte farklı renkleri ( $\mathrm{f}=11)$ kullanarak eğitim sistemini yapı ve süreç açısından eleştirerek çıktılarından memnuniyetsizliklerini dile getirmişlerdir. Örneğin engellerle dolu iki yoldan birisinin ucunda yeşil bir ağaç, diğerinde ise siyah çizgilerden oluşan bir karmaşıklık çizen öğretmen adayı şöyle açıklama yapmıştır (K30): "Yürümek zorunda olduğun engel ve zorluklarla dolu bir yoldur. Ya kazanirsin ya kaybedersin.".

Diğer taraftan, katılımcıların çizgileri kullanarak ürettikleri metaforların açıklamalar analiz edildiğinde 5'i olumlu, 16'i olumsuz ve 5'ü olumlu-olumsuz gruplarda değerlendirilmiştir. Alınan eğitimin sonunda hiçbir ş̧ey elde edilemeyeceğine dair umutsuz görüşler düz, eğri, dikey ve 'zigzag'lar içeren çizgiler yoluyla belirtilmiştir.

\section{TARTIŞMA ve SONUÇ}

Çalışmada öncelikle öğretmen adaylarının Türk eğitim sistemini tüm boyutları ve dinamikleri ile ele alabildikleri ve analiz edebildikleri görülmüştür. Öğretmen adayları eğitim sistemine ilişkin genel olarak daha fazla olumsuz metafor üretmişlerdir. Ayrıca, temalar arasında karşılaştırma yapıldığında, olumlu ve olumlu-olumsuz gruplarında kullanılan metaforların kullanılmasının nedenleri daha çok eğitim kavramına yüklenilen olumlu anlamdan kaynaklandığı görülmektedir. Alanyazında yapılan bazı çalışmalarda da eğitim sistemine yönelik kullanılan mecazların eğitim, okul, öğretmen gibi kavramlara göre daha olumsuz olduğu belirtilmiştir (Gözler, 2017; Kasapoğlu, 2016; Örücü, 2014). Nitekim çalışmada, tüm zorluklara ve fazlasıyla çaba gerektiren bir yol olmasına rağmen, eğitimin bireysel ve toplumsal getirilerinden dolay1 gerekli ve zahmete değer olduğu ifade edilmiştir. Öte yandan, eğitim sistemini girdi-süreç-çıktı (13 farkl1 kavram) olarak ele alan başka bir çalışmada, fen-edebiyat ve eğitim fakültesi öğrencilerinin çıktı ile ilgili (mezun) kısmen olumsuz metaforik algıları dışında diğer kavramlarla ilgili algıları olumlu bulunmuştur (Keser-Özmantar ve Yalçın-Arslan, 2019). Farklı çalışmalarda ayrı olarak ele alınan girdi boyutundaki öğretmen, okul müdürü, olumlu algılar bulunması, kavramların tek tek alındığında ve birlikte uyumlu çalışmasını gerektiren bütün olarak ele alındığında algıların değiştiğini göstermektedir. Nitekim iyi işleyen ve işlevsiz eğitim sistemini ele alırken de bu temel ögeler değerlendirilerek algılanan gerçek ortaya koyulmaktadır. Erginer (2011) çalışmasında üretilen metaforlardan, iyi işleyen bir eğitim sisteminin dinamikleri arasında uyumlu bir çalışma olduğu, kötü işleyen bir eğitim sisteminde ise bu sistemin yürütülmesinde sorunlardan kaynaklandığı sonucuna varmıştır.

Çalışma öğrencilerin görsel metafor yoluyla yaratıcılıklarını kullanarak eğitim sistemine ilişkin algılarını ortaya koyma noktasında özgünlük kazanmıştır. Bitki metaforu üzerinden katılımcılar, ağaçların kök ve dalları, papatyanın yaprakları gibi özelliklerden yararlanarak eğitim sistemini güçlü, çok boyutlu ve çok yönlü olması özelliklerini vurgularken, kısa ömürlü bitki olması nedeniyle ot ve papatya falı benzetmesinden dolayı papatya gibi bitki metaforlarını kullanarak sürekli yapılan değişikliklerin ve uygulanan istikrarsız politikaların niteliksiz ve verimsiz bir sisteme dönüştüğünü eleştirmişlerdir. Yaşar ve Sözbilir (2017) tarafından yapılan çalışmada benzer şekilde yapısal-yönetimsel sorunlar Türk Eğitim Sistemi ile ilgili öğretmen adaylarının dile getirdikleri sorunların başında eğitim sisteminin sürekli değiştirilmesi yer almıştır. Benzer şekilde Kasapoğlu (2016) ve Gözler (2017) de yaptıkları metafor çalışmalarında, öğretmen adaylarının, Türk eğitim sistemini en fazla değişken, düzensiz (karmaşık), sorunlu, gelişim göstermeyen ve işlevsiz yapılar olarak tanımladıkları görülmektedir. Yapılan sürekli değişikliklerin de benzer şekilde belirsizliğe ve karmaşıklı̆̆a yol açtığ (Kasapoğlu, 2016; Örücü, 2014). Bununla ilgili olarak, Boyacı (2009) ilköğretim öğretmenleriyle eğitim planması kavramını incelediği metafor çalışmasında, planlama sürecinin örgüt hiyerarşinin alt basamaklarında bulunan paydaşların görüşleri alınmadan ve araştırma yapılmadan gerçekleştiriltiğini ortaya koymuştur. Dolayısıyla yapılan eğitim reformlarından beklenen dönüşüm yetersiz kalmaktadır.

Hayvan metaforu üzerinden katılımcılar, inek, kuş, tırtıl ve aslan gibi hayvan metaforları aracılığıyla, eğitimin bireysel ve toplumsal getirilerine vurgu yaparken üretkenliği artırarak toplumsal kalkınma katkıda bulunacağını ifade etmişlerdir. Diğer taraftan ise, kaplumbağa, bukalemun, at, kelebek ve ahtapot gibi hayvanların yavaşlık, değişkenlik, hız ve kısa ömürlülük gibi özelliklerinden yararlanarak, çağın gerektirdiği bilgi ve beceri kazandırmada Türk eğitim sisteminin bireylerin ihtiyaçlarını karşılamada yetersiz kaldığını, yenilikleri geriden takip ettiğini, sürekli yapılan değişiklikleri, rekabete dayalı verimsiz buldukları eğitim sistemini eleştirmişlerdir. Bu sonuçların nedenlerine ilişkin olarak, eğitim programını ele 
alan bir çalışmada, eğitim programı yol gösterme, dinamiklik ve kapsamlılık özelliklerinden ötürü olumlu algılanırken, uygulamadaki farklılıklardan dolayı engelleme, zorunluluk, tep tipleştirme, değişkenlik gibi anlamlar içeren metaforlarla ifade edilmiştir (Yıldız, Özen, ve Yıldız, 2018). Benzer şekilde, Örücü'nün (2014) çalışmasında, okula yönelik yapılan eleştirel metaforlar okulların tek-tip insan yetiştirmesi ve bireylerin yaratıcılığını öldürmesi açıklamaları dile getirilmiştir. Eğtim sisteminin süreç boyutuna ilişkin rekabete dayalı olması sorununa ilişkin, Yaşar ve Sözbilir (2017) tarafından yapılan çalışmada, en fazla dile getirilen sorun sınav odaklı bir ölçme-değerlendirme sistemi olmuştur. Eğitim sisteminin ölçmedeğerlendirme uygulamalarını ele alan çalışmaların sonucunda, öğretmen adaylarının eğitim-öğretim niteliğini artıran ve iyi işlemesi gereken uygulamalar olması gerektiğini belirterek daha çok olumlu metaforlar ortaya çıkarken (Taşdemir ve Taşdemir, 2016), aynı zamanda ölçme-değerlendirme sisteminin korku-yılgınlık-kaygı yaratan, ezbere dayanan, adil olmayan, hayatı belirleyiciliği öne çıkan, değişken yönleri de belirtilmiştir (Baş \& Kıvılcım, 2019; Taşdemir \& Taşdemir, 2016). Eğitim örgütlerinin süreç boyutunu etkileyen ölçme-değerlendirme uygulamaları sistemin çıktılarını doğrudan etkilemektedir. İyi işleyen bir değerlendirme sistemi eğitimin etkililiği için de önemli bir koşul oluşturmaktadır.

Renk ve çizgileri kullanarak üretilen metaforlarda karmaşıklık ve kaosa yönelik görüşler siyah ve koyu renkler ile eğri, zigzag çizgiler aracılığıyla belirtilmiştir. Alanyazında benzer şekilde öğretmen adaylarının Türk eğitim sistemine ilişkin algılarının kaosa dönüşen belirsizlik, karmaşıklık ve zorluklar barındırdığı görülmektedir (Gözler, 2017; Kasapoğlu, 2016; Örücü, 2014). Araştırma sonuçları öğretmen adaylarının eğitim sisteminin amaçları hakkında olumlu algılara sahipken, sistemin yapı-süreç-hava boyutlarıyla ilgili aksaklıklardan dolayı olumsuz bir algıya sahip olduklarını göstermektedir.

Çalışma sonuçları işlenen ve potansiyel işleyen girdi olarak öğretmen adaylarının daha çok olumsuz bir eğitim sistemi algılarının bulunduğunu göstermiştir. Öğretmen adayları eğitimi girdi olarak değerli ve kaçınılmaz bir yatırım olarak görürken, uygulamaya yönelik sorunların eğitimin hedeflerine ulaşmasına engel olduğunu düşünmektedir. Bunun yanı sıra, öğretmen adayları, eğitimin zorlu, engellerle dolu ve emek isteyen bir süreç olduğunu belirtmiş; fakat bu sürecin sonunda sınav odaklı ve rekabete dayalı sistemden dolayı herkesin mutlu olmadığını ve bireylere katkısını eleştirmişlerdir. Dolayısıyla, eğitim sisteminin bireylerin beklenti ve isteklerine karşılık vermediği ifade edilmiştir. Eğitimin hedeflerine ulaşmasını engelleyen nedenlerden biri olarak, öğretmen adayları eğitim sisteminin sürekliliğini olumsuz yönde etkileyen, eğitim politikalarında sıklıkla yapılan değişiklikleri göstermiştir. Katılımcılar kullandıkları bitki, hayvan, renk metaforlarıyla eğitim sisteminin siyasi, ekonomik, yönetimsel faktörlerinden olumsuz yönde etkilenmesini eleştirmişlerdir.

Metaforlar gerçeği yansıtmanın yanı sıra aynı zamanda onu şekillendirebilirler (Inbar, 1996). Dolayısıyla eğitimin işlenen girdisi ve işleyen çıktısı olarak öğretmen adaylarının eğitim sistemine ilişkin olumsuz algıları dikkate alınıp nedenleri araştırılarak, eğitim sisteminin yeniden şekillendirilmesinde karar vericiler tarafindan kullanılabilir. 


\section{EKLER}

Ek 1. Metafor örnekleri

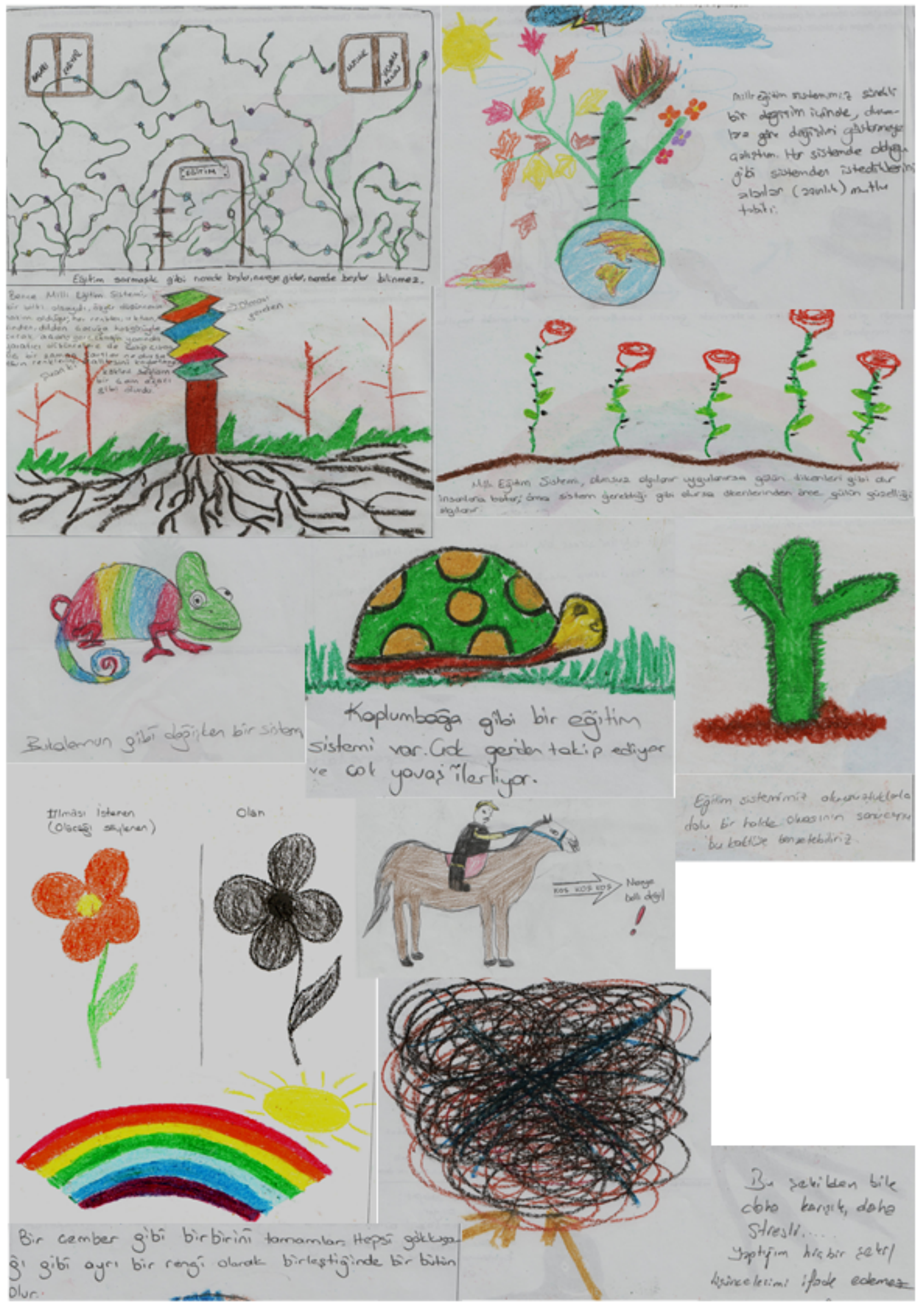




\section{KAYNAKLAR}

Akan, D., Yalçın, S., \& Yıldırım, İ. (2014). Okul mdürü kavramına ilişkin öğretmenlerin metaforik algıları. Ilkögretim Online, 13(1).

Aldemir, C., \& Barbato, R. (1983). Yönetim biçimleri, örgüt yapısı ve başarım. Amme İdaresi Dergisi, 16(4), 120130.

Aykaç, N., \& Çelik, Ö. (2014). Öğretmenlerin ve öğretmen adaylarının eğitim programına ilişkin metaforik algılarının karşılaştırılması. Eğitim ve Bilim, 39(173), 328-340.

Baş, G., \& Kıvılcım, Z. S. (2019). Türkiye'de öğrencilerin merkezi sistem sınavları ile ilgili algıları: bir metafor analizi çalışması. Egitimde Nitel Araştırmalar Dergisi - Journal of Qualitative Research in Education, 7(2), 639-667.

Boyac1, A. (2009). Metaphorical images for educational planning: Perceptions of public elementary school teachers. Selcuk University Journal of Social Sciences Institute, O(21), 111-124.

Bursalığlu, Z. (2015). Okul yönetiminde yeni yapı ve davranış (19. Basım). Ankara: PegemA Yayıncılık.

Creswell, J. W. (2013). Qualitative inquiry and research design: Choosing among five approaches (3rd ed.). Thousand Oaks, CA: Sage Publications.

Döş, İ. (2010). Aday öğretmenlerin müfettişlik kavramına ilişkin metafor algıları. Gaziantep Üniversitesi Sosyal Bilimler Dergisi, 9(3), 607-629.

Erginer, E. (2011). A metaphorical analysis of the meanings attributed to the education system by university students: A case study. Education, 131(3), 653-662.

Gözler, A. (2017). Türkçe öğretmeni adaylarının türk eğitim sistemi algıları: Bir metafor çalışması. Kırşsehir Eğitim Fakültesi Dergisi, 19(2), 1341-1356.

Gültekin, M. (2013). İlköğretim öğretmen adaylarının eğitim programı kavramına yükledikleri metaforlar. Eğitim ve Bilim, 38(169), 126-141.

Günbay1, İ. (2011). Principals' perceptions on school management: A case study with metaphorical analysis. International Online Journal of Educational Sciences, 3(2), 541-561.

Güney, S. (2000). Davranış bilimleri (15. Basım). Ankara: Nobel Akademi Yayıncılık.

Hoy, W. K., \& Miskel, C. G. (2010). Eğitim yönetimi: Teori, araştırma ve uygulama. (S. Turan, Ed.) (7. Baskı). Nobel Yayın Dağıtım.

Inbar, D. (1996). The free educational prison: Metaphors and images. Educational Research, 38(1), 77-92.

İpek, C. (2014). Yönetim teorileri. In Türk Eğitim Sistemi ve Okul Yönetimi (6. Baskı). Ankara: Pegem Akademi.

Kad, A., \& Beytekin, O. F. (2017). Metaphorical perceptions of teachers, principals and staff on school management. Journal of Education and Practice, 8(15), 29-35.

Kasapoğlu, H. (2016). Analysis of teacher candidates perception's of Turkish national education system through metaphors. Educational Administration: Theory and Practice, 22(1), 59-80.

Kaynak, T. (1990). Organizasyonel davranış. İstanbul: İşletme İktisadı Enstitüsü Yayınları No. 223.

Keser Özmantar, Z., \& Yalçın Arslan, F. (2019). Metaphorical perceptions of prospective EFL teachers related to Turkish education system. Pegem Ĕgitim ve Ögretim Dergisi, 9(1), 255-304.

Koçel, T. (1983). Yönetim kavram ve teknikleri (No: 123). İstanbul: İşletme Fakültesi Yayını.

Lakoff, G., \& Johnson, M. (1980). Conceptual metaphor in everyday language. The Journal of Philosophy, 77(8), 453.

Memduhoğlu, H. B. (2014). Türk eğitim sisteminin örgüt ve yönetim yapısı. In Türk Eğitim Sistemi ve Okul Yönetimi. Ankara: Pegem Akademi.

Memduhoğlu, H. B., \& Mazlum, M. M. (2014). Bir değişim hikayesi: Eğitim denetmenlerine ilişkin metaforik algılar. Trakya Üniversitesi Eğitim Fakültesi Dergisi, 4(1), $28-47$.

Merriam, S. B. (2013). Nitel Araştırma. Ankara: Nobel Akademi Yayıncılık.

Miles, M. B., \& Huberman, A. M. (1994). Qualitative data analysis: An expanded sourcebook (2nd ed.). Thousand Oaks, CA: Sage Publications.

Morgan, G. (1986). Images of Organization. US: SAGE Publications Inc.

Örücü, D. (2014). Öğretmen adaylarının okul, okul yönetimi ve Türk eğitim sistemine yönelik metaforik algıları. Kuram ve Uygulamada Ĕ̈itim Yönetimi Dergisi, 20(3), 327-358.

Saban, A. (2009). Öğretmen adaylarının öğrenci kavramına ilişkin sahip oldukları zihinsel imgeler. Türk Ĕgitim Bilimleri Dergisi, 7(2), 281-326.

Saban, A., Koçbeker, B. N., \& Saban, A. (2006). An investigation of the concept of teacher among prospective teachers through metaphor analysis. Educational Sciences: Theory \& Practice, 6(2), 509-522.

Şahin, A., \& Sabanc1, A. (2018a). Perceptions of prospectiveteachers attanding pedagogical formation courses regarding the school administrators and teachers: A metaphorical study. Turkish Studies, 13(4), 1057-1082.

Şahin, A., \& Sabanc1, A. (2018b). The perception of pedagogical formation students have towards educational concepts: Metaphoric study. Journal of Education and Future, (13), 179-207.

Sengul Bircan, T. (2018). Metaphors of history teachers candidates in Turkey on teaching profession. International Journal of Educational Methodology, 4(2), 83-93.

Şişman, M. (1994). Örgüt kültürü: Eskişehir il merkezindeki ilkokullarda bir araştırma. Eskişehir: Anadolu Üniversitesi Yayını.

Taşdemir, M., \& Taşdemir, F. (2016). Ölçme ve değerlendirme uygulamaları hakkında öğretmen adayı görüşlerinin 
metafor yoluyla analizi. Turkish Studies, 11(9), 775-802.

Tidwell, D., \& Manke, M. P. (2009). Making meaning of practice through visual metaphor. In D. Tidwell, M. Heston, \& L. Fitzgerald (Eds.), Research Methods for the Self-Study of Practice (pp. 135-154). Springer Science \& Business Media.

Yalçın, M., \& Erginer, A. (2012). İlköğretim okullarında okul müdürüne ilişkin metaforik algılar. Öğretmen Ĕgitimi ve Ĕgitimcileri Dergisi, 1(2), 229-256.

Yapıcı, M., \& Yapıcı, Ş. (2013). Öğretmen adaylarının pedagojik formasyona ilişkin metaforları. Turkish Studies, 8(8), 1421-1429.

Yaşar, M. D., \& Sözbilir, M. (2017). Fen bilgisi öğretmen adaylarının Türk eğitim sistemine yönelik görüşleri: Güncel sorunlar ve çözüm önerileri. Çukurova Üniversitesi Eğitim Fakültesi Dergisi, 46(1), 165-201.

Yildiz, S., \& Gizir, S. (2018). A phenomenological study of the perceptions of candidate teachers about the concepts of school, teacher and student in their dreams. International Journal of Instruction, 11(2), 309-324.

Yıldırım, A., Ünal, A., \& Çelik, M. (2011). Öğretmen kavramına ilişkin öğretmen, yönetici ve müfettiş algılarının analizi. Uluslararasi Insan Bilimleri Dergisi, 8(2), 92-109.

Yıldız, S., Özen, R., \& Yıldız, K. (2018). Temel eğitimi bölümü öğretmen adayları ve eğitim programı: Bir metafor çalışması. International Journal of Social Sciences and Education Research, 4(1), 165-184.

Yıldızlı, H., Acar Erdol, T., Baştuğ, M., Bayram, K., \& Bayram, K. (2018). Türkiye’de öğretmen kavramı üzerine yapılan metafor araştırmalarına yönelik bir meta-sentez çalışması. Eğitim ve Bilim, 43(193), 1-43. 